\title{
マグネシアの表面物性に及ぼす焼成温度の効果
}

\section{The Effect of Calcining Temperature on the Surface Properties of Magnesia}

\author{
Kunio Esumi* and Kenjiro Meguro* \\ *Department of Applied Chemistry, Faculty \\ of Science, Science University of Tokyo \\ 1-3, Kagurazaka, Shinjuku-ku, Tokyo
}

\begin{abstract}
The electron donor properties of magnesia were investigated by means of 7, 7,8,8-tetracyanoquinodimethane (TCNQ) adsorption. The radical-forming activity, i. e., the relative TCNQ anion radical concentration, was measured as a function of magnesia calcining temperature which was varied from 200 to $800^{\circ} \mathrm{C}$. The result showed that the concentration of the electron donor sites on magnesia which can reduce TCNQ to the corresponding anion radical depends upon the calcining temperature and has the minimum value at $500^{\circ} \mathrm{C}$. It was recognized from infra-red studies thatutw absorption bands are present at 3,720 and $3,640 \mathrm{~cm}^{-1}$ on the surface of magnesia and the intensities of the two bands changes against the calcining temperature. A correlation was found to exist between the concentration of electron donor sites, presumably, the concentration of surface hydroxyl ions, and the radical-forming activity.
\end{abstract}

要旨

マグネシアの電子供与性を TCNQ 吸着により研究し た。ラジカル生成度 (TCNQ 陰イオンラジカルの相対 濃度）を 200 から $800^{\circ} \mathrm{C}$ なで変化させたマグネシアの焼 成温度の関数として測定した。その結果，TCNQ を還 元し TCNQ 陰イオンラジカルにできるようなマグネシ アの電子供与点は焼成温度に依存しており, 焼成温度 $500^{\circ} \mathrm{C}$ で最小濃度を示した。IR スペクトルの測定から， マグネシア表面に $3,720,3,640 \mathrm{~cm}^{-1}$ 飞吸収をるつ水 酸基が存在し，それらの吸收強度は焼成温度に上り変化 していることが認められた。電子供与点である表面水酸

* 昭和 50.3.4 受理
基イオンの量とラジカル生成度の量との間によい相関が あった。

\section{1. 緒言}

熱処理による粉体の構造や物理化学的性質などの变化 については多くの研究1),2) がある。マグネシアは体質顔 料，充てん剂なぞとして用いられ，熱処理によるその表 面物性変化は重要な役割をしていると考えられる。そこ で，マグネシアの熱処理による表面物性の変化を強い電 子受容体である $7,7,8,8$-テトラシアノキノジメタン (TCNQ) 吸着により，ESR，電子スペクトル，IR など を用いて調べた結果を報告する。 
2. 実

験

\section{1 試 料}

試料は市販特級のマグネシアを用いた。熱処理として は，シリカボートに入れた試料を電気灯中で一定温度で 2 時間焼成し, その焼成温度範囲を $200 \sim 800^{\circ} \mathrm{C}$ とし た。 $\mathrm{TCNQ}^{3)}$ は 1,4-シクロヘキサンジオンとマロノニ トリルの生成物から合成し，再結晶して用いた。市販特 級のアセトニトリルを溶媒として用いた。

\section{2 装置および操作}

比表面積は液体空素温度に拉ける $\mathrm{N}_{2}$ ガス吸着から， $\mathrm{BET}$ 法により， $100^{\circ} \mathrm{C}$ で 1 時間排気した試料について の測定により求めた。

IR 吸収スペクトルは日立の EPI-G3 型 IR 分光計を 用い， $\mathrm{NaCl}$ 空に装着した石英セル中で測定した。試料 を执よそ $6.5 \mathrm{mg} / \mathrm{cm}^{2}$ の厚さのウェーファにプレスし， セルに入れ $100^{\circ} \mathrm{C}, 10^{-5}$ Torr で 1 時間排気した。その 後，真空中で室温まで泠やしスペクトルを記録した。

熱処理した試料をL字管に入れ，100 $\mathrm{C} ， 10^{-5}$ Torr で 1 時間排気した後，真空中で $25^{\circ} \mathrm{C}$ まで冷やした。その 後, TCNQ のアセトニトリル溶液 $(10 \mathrm{mM}, 20 \mathrm{~m} l)$ を L字管中の試料にストップコックを通して加党, $25^{\circ} \mathrm{C}$ で 2 時間振とうした。振とう後, 試料を遠心分離して集 め室温, 真空中で乾燥した。乾燥した試料を電子スペク トル測定に用い，ESR 測定ではさらに $10^{-5}$ Torr で排 気して用いた。

ESR スペクトルは日本電子製 JES-3BS-X 型 ESR
装置により測定した。 $g$-值は標準物質である $\mathrm{Mn}^{2+}$ の值 と比較して得た。ラジカル生成度（試料の単位表面積当 たりの相対ラジカル数）は，試料の吸収と $\mathrm{Mn}^{2+}$ の吸収 との大きさの比較により算出した。

電子スペクトルは日立製 EPS-3 T 型分光光度計に同 社製積分球を装着して測定した。

\section{3. 結果および考察}

強電子受容体であるテトラシアノエチレン (TCNE) やトリニトロベンゼンを吸着することによって，金属酸 化物表面の電子供与性を調べた研究4 7) が報告されてい る。Flockhart ${ }^{4)}$ らはいろいろの温度で排気処理したア ルミナに，TCNE を吸着することによりその表面に 2 種類の電子供与点が存在することを認めている。

TCNQ をそのアセトニトリル溶液から，200から 800 ${ }^{\circ} \mathrm{C}$ の間で焼成したマグネシアに吸着させると, 特徵的

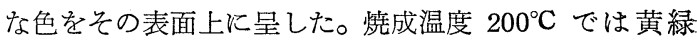
色，300ㄷ 以上ではうすい青色となった。マグネシア表 面の色の変化は新しい吸着種がその表面に生成している ことを示すものである。このことは色のついた試料がフ リーラジカル種の存在を示す ESR 吸収をあらわすとい うことにより確認される。その ESR スペクトルは超微 細構造を示さない（図-1；g-值，2.003）。これは超微細 構造の異方性が運動の自由度の不足から生じるという事 実により説明することができる。吸着種の状態を電子ス ペクトルにより調ベた。焼成温度の違いによる電子スペ クトルの变化は，皃とんど観測されなかった。図-2 に

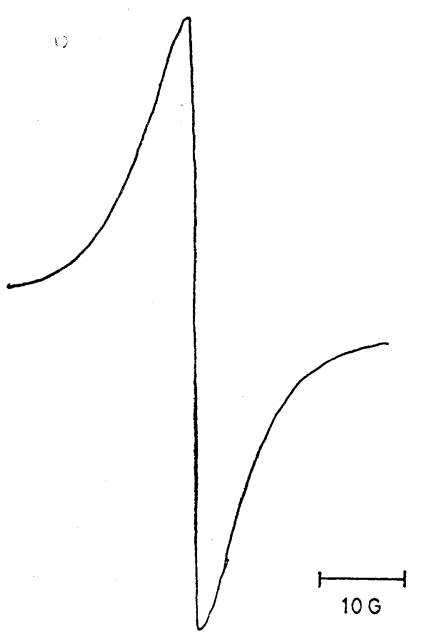

Fig. 1. ESR spectrum from TCNQ adsorbed on magnesia calcined between $200^{\circ} \mathrm{C}$ and $800^{\circ} \mathrm{C}$

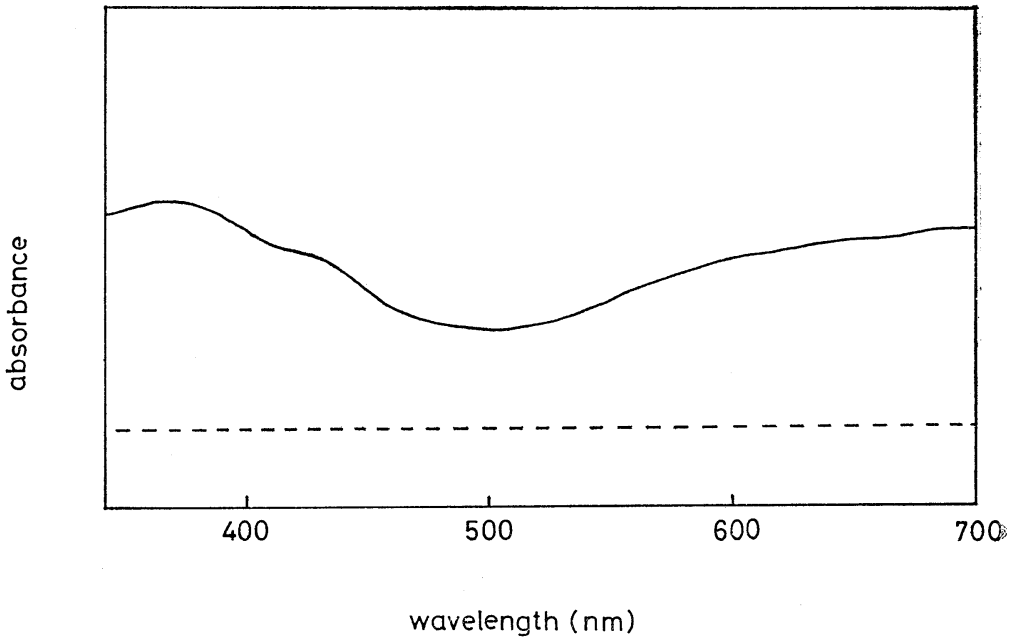

Fig. 2. Electronic spectra from $\mathrm{TCNQ}$ adsorbed on magnesia. Dotted line, $\mathrm{MgO}$ prior to aesorption 


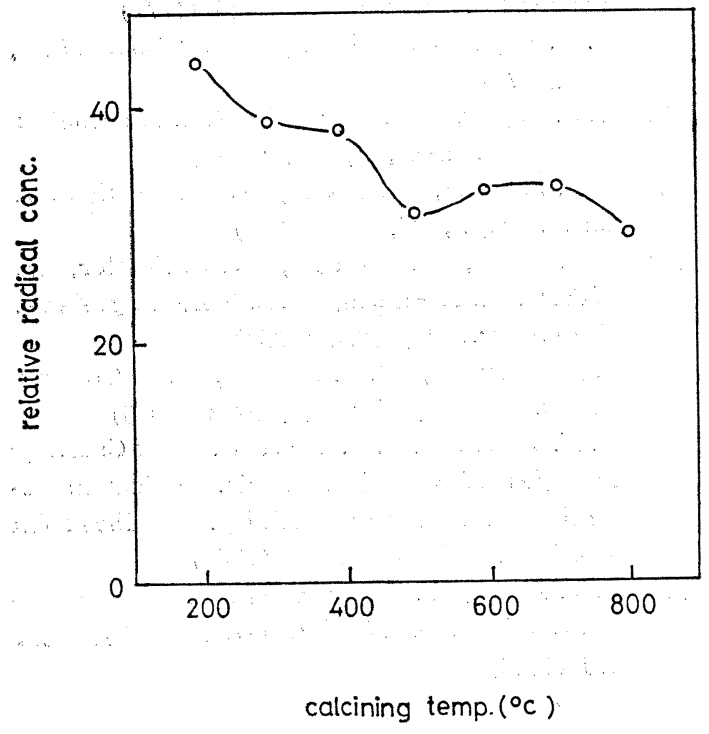

Fig. 3. Radical-forming activity of magnesia as a function of calcining temperature with TCNQ as adsorbate

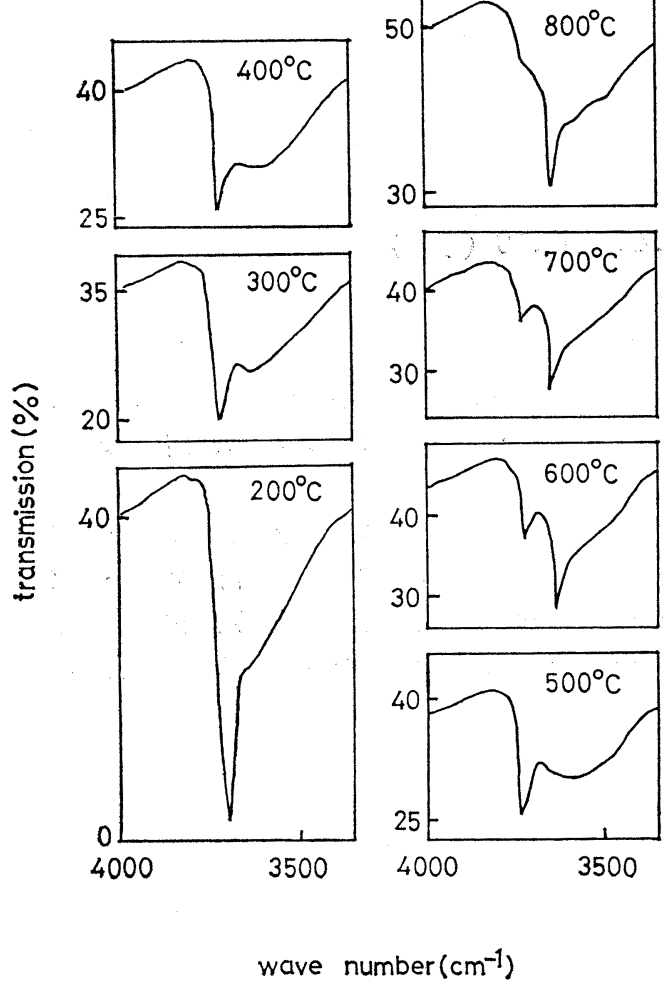

Fig. 4. Change of infra-red spectra of magnesia with calcining temperature
その電子スペクトルを示す。 $450 \mathrm{~nm}$ 以下に観測される 吸収はニュートラルな TCNQ の物理吸着した状態に対 応していると考えられる。このことはニュートラルな TCNQ がそのアセトニトリル溶液中で $\left.395^{3}\right) \mathrm{nm}$ に吸取 をあつことから推察される。また， $600 \mathrm{~nm}$ 付近にみら れる吸收はニュートラルな TCNQ やマグネシア自身の 吸収としては帰属できないが，6438) $\mathrm{nm}$ に吸収をるつ ダイマー TCNQ 陰イオンラジカルから生じていると思 われる。このことは TCNQ が高い電子親和力をもち, また TCNQ 陰イオンラジカルの誘導体が室温でさえも 安定である ${ }^{9 \sim 11)}$ そいら事実により示唆される。以上の結 果から，マグネシア表面から TCNQ への電子移動の結 果として，テジカルイオンが生成することが ESR や電 子スペクトルにより確認された。

マグネシアのラジカル生成度に及ぼず燒成温度効果を 図-3 に示す。図-3 から分かるよらに, ラジカル生成度 は燒成温度と共に減少し, $500^{\circ} \mathrm{C}$ で最小值をもち, その 後增加する。この結果は電子供与点が焼成温度により変 化していることを示している。詳細に焼成したマグネシ ア表面を研究するために, TCNQ 吸着前のマグネシア のIR スペクトルを測定した。図-4 は焼成温度による マグネシアの IR スペクトルを示している。図より明ら かなように，2つの表面水酸基が $3,720,3,640 \mathrm{~cm}^{-1}$ に 観測される。 $3,720 \mathrm{~cm}^{-1}$ の吸収強度は焼成温度 200 $500^{\circ} \mathrm{C}$ の間で徐々に減少し, それょり高温では急激に減 少している。また, $3,640 \mathrm{~cm}^{-1}$ の吸収は焼成温度 $600^{\circ} \mathrm{C}$ 以上で現われ，その吸収強度は焼成温度の増加之共飞増 加している。マグネシア表面上に 2 つの表面水酸基の存 在が Anderson ${ }^{12)}$ らにより確認されている。水酸基イ オンのイオン化ポテンシャルは比較的小さい $(\sim 2.6$ $\mathrm{eV}^{13)}$ ，気相中)。それゆえ, 水酸基イオンから電子受容 体に電子移動する可能性がある。実際に, Fomin ${ }^{14)} ら$ は適当な受容体分子が存在する溶媒系に打いて, 水酸基 イオンからの電子移動が生じることを示している。 $\mathrm{Che}^{5)}$ らはマグネシア表面の電子供与点は水酸基イオン に基づくものであることを述べている。上述のことを考 慮すると, 図-3 と示したマグネシアのラジカル生成度 の結果は, 次のように説明することができると考号れ る。焼成温度 $200 \sim 500^{\circ} \mathrm{C}$ の間でのラジカル生成度の減 少は, $3,720 \mathrm{~cm}^{-1}$ 飞吸収をるつ表面水酸基数の減少に 対応している。それに続いてのラジカル生成度の增加 は, $3,640 \mathrm{~cm}^{-1}$ に吸収をもつ表面水酸基数の増加に対 応している。

以上の結果から, 低温焼成のマグネシアではその電子 供与点は主に $3,720 \mathrm{~cm}^{-1}$ 飞吸収をるつ表面水酸基であ 
り, 高温焼成のものでは, $3,640 \mathrm{~cm}^{-1}$ に吸収をもつ表 面水酸基に基づくものであることが確認された。

なお実験に協力された島田博彰氏に感謝致します。

\section{参考文献}

1) R. I. Razouk, R. Sh. Mikhail : J. Phys. Chem., 62, 920 (1958)

2) A. Bielan̂ski, J. Sloczyński : J. Catalysis, 4, 324 (1965)

3) D. S. Acker, W. R. Hertler: J. Amer. Chem. Soc., 84, 3370 (1962)

4) B. D. Flockhart, I. R. Leith, R. C. Pink : Trans. Faraday Soc., 65, 542 (1969)

5) M. Che, C. Naccache, B. Imelik : J. Catalysis, 24, 328 (1972)

6) A. J. Tench, R. L. Nelson : Trans. Faraday Soc., 63, 2254 (1967)

7) T. Iizuka, H. Hattori, Y.Ohno, J.Sohma, K.
Tanabe : J. Catalysis, 22, 140 (1971)

8) R. H. Boyd, W. D. Phillips : J. Chem. Phys., 43, 2927 (1965)

9) R. G. Kepler, P. E. Bierstedt, R. E. Merrifield : Phys. Rev. Lett., 5, 503 (1960)

10) D. B. Chesnut, H. Foster, W. D. Phillips : J. Chem. Phys., 34, 684 (1961)

11) L. R. Melby, R. J. Harder, W. R. Hertler, W. Mahler, R. E. Benson, W. E. Mochel : J. Amer. Chem. Soc., 84, 3374 (1962)

12) P. J. Anderson, R. F. Horlock, J. F, Oliver : Trans. Faraday Soc., 61, 2754 (1965)

13) V. M. Vedeneev, L. V. Gurvich et al. : Cleavage Energies of Chemical Bonds. Ionization Potentials and Electron Affinity. Handbook (in Russian), Izd. AN SSSR (1960)

14) G. V.Fomin, L. A. Blyumenfel'd, V. I. Sukhorukov : Proc. Acad. Sci. (U.S.S.R.), 157, 819 (1964)

\section{色 材 協 会 誌 Vol.48 No.10 (予告)}

報文

漆塗膜の硬化に及ぼす不飽和脂肪酸メチルエステルの影響

エポキシ樹脂の硬化に関する研究（第 4 報）

国立文化財研究所 見 城 敏 子 他 京都市工業試験場 加 門 隆 他

テーマ資料（エマルション塗料）

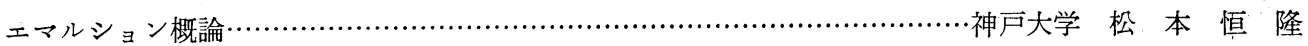

エマルションポリマーの塗料への応用…………………..棟インキ化学工業(株) 河 井 一 郎

エマルション塗料…………………………….............................本油脂(株) 疋 田! 淳

マスチック塗料…………………………………..............恒和化学工業(株) 松 本 能 治

特許 公 告

文献 